\title{
ОЦІНКА ВИСОКОШОВКОНОСНИХ ЛІНІЙ ШОВКОВИЧНОГО ШОВКОПРЯДА (ВОМВYХ MORI L.) ЗА ЖИТТЄЗДАТНІСТЮ ТА ПРОДУКТИВНІСТЮ
}

\author{
Панченко Ольга Михайлівна \\ науковий співробітник \\ Інститут тваринництва НАAН \\ ORCID: 0000-0001-9580-2839 \\ E-mail: labinform@i.ua
}

\author{
Маркіна Тетяна Юріївна \\ доктор біологічних наук, профресор \\ Харківський національний педагогічний університет імені Г.С.Сковороди \\ ORCID: 0000-0002-6313-9814 \\ E-mail: t.yu.markina@gmail.com
}

У статті представлено результати досліджень високошовконосних високоінбредних ліній шовковичного шовкоnряду Bombyx mori L. Г2, Г4, Г6 та Г7 за показниками життєздатності та продуктивності для одержання високоякісного біоматеріалу комах. Селективні лінії представляють інтерес для вивчення у зв'язку з високою шовконосністю та високим ступенем інбридингу, оскільки підлягали постійному жорсткому відбору за селекційними індексами за ознаками шовконосність та маси шовкової оболонки впродовж одинадияти поколінь з індивідуальним підбором пар для схрещування. Саме селекційні прийоми можуть сприяти підвищенню ефективності виробництва культур комах за для задоволення потреб сучасних високотехнологічних напрямів. Порівняльна оцінка високошовконосних високоінбредних ліній за показниками життєздатності та продуктивності показала, що за сукупністю біологічних та технологічних показників як найкращі були виділені лінії Г6 та Г7. 3 найкращими показниками за життєздатністю гусениць у весняну вигодівлю

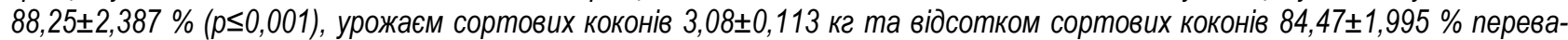
жала лінія $Г 7$, яка була відібрана для вивчення гусеничної стадії та формотворення коконів. За результатами літньої вигодівлі була відібрана, як найкраща - лінії Г6, що відрізнялася найвищими показниками життєздатності гусениць $(71,8 \pm$ 4,18 \%) та ії прямі гібриди з іншими лініями, які мали стабільно високі показники в межах 79,8-83,1 \%. Реципрокні комбінаиії лінії Г6 з Г2 та Г7 також мали високі показники життєздатності гусениць (79,14 та 78,98 \% відповідно). Це вказує на високу специфічну комбінаційну здатність лінії за показником, що вивчається, що є підгрунтям для дослідних робіт за даною селективною ознакою. Напрацювання високоякісного біоматеріалу шовковичного шовкопряду сприяє розширенню можливостей його використання у різних сферах. У фармакології та медицині, як джерело хітозану, у природоохоронній сффері, як тест-об'єкту біоіндикаційних досліджень, у тваринництві, як цінний кормовий ресурс. Залишаються актуальними традиційні сфрери його використання, зокрема як продуцента натурального шовку.

Ключові слова: шовковичний шовкопряд Bombyx тоri L., селекція, лінії та гібриди, розведення комах, життєздатність, продуктивність.

DOI: https://doi.org/10.32845/bsnau.lvst.2020.4.10

Шовковичний шовкопряд Bombyx mori L., залишаючись основним продуцентом натурального шовку, набуває все більшого значення в інших програмах технічної ентомології [6, 9], тобто масового розведенням комах, всебічне використання яких в світі останнім часом зростає [19]. Комах все частіше розглядають як цінний кормовий ресурс для тварин і людини [17, 20]. Гусениць-мурашів шовковичного шовкопряду використовують як біоіндикаторів стану навколишнього середовища [7].

Натуральний шовк активно використовується в різних галузях господарської діяльності: авіації, медицині, легкій промисловості, в радіо- та електротехніці, млиновому виробництві, фото- і кінематографії та в ряді інших галузей народного господарства.

На сьогодні небувало зріс інтерес до біополімерів, серед яких все більшого практичного використання набуває хітозан, що виділяють із панцира ракоподібних та лялечок шовковичного шовкопряду. Чим більше вчені дізнаються про властивості хітину і хітозану, тим ширше сфрера їх практичного використання. I з кожним роком виникають абсолютно нові і несподівані напрямки. До числа основних напрямків використання хітозану можна віднести медицину, сільське

господарство, косметологію і харчову промисловість $[11,14]$. Розроблено методику, яка забезпечує отримання високоочищеного хітозану високої якості з Bombyx mori [10].

Вохидова Н.Р. та ін. [4] провели значні дослідження щодо вивчення біологічно активних властивостей полімер металевих систем хітозану шовковичного шовкопряду (X3, X3-Cu2 ${ }^{+}$, X3-Со2+, хітозан-метал в умовах in vitro) 3 пригнічення фітопатогенних грибів, для профрілактики і лікування моніліозу плодових культур. Вивчена фунгіцидна активність хітозану і його наноструктурованих систем з міддю, які активно пригнічують ріст і розвиток фітопатогенних грибів Fusarium solani 169 i Verticillium dahliae 57 [21]. Хітозан, одержаний із хітину лялечок шовковичного шовкопряду, $€$ природним біостимулятором, який може бути використаний при лікуванні термічних опіків [16]. Досліджено антибактеріальні і антитоксичні властивості хітозану та його похідних (хітозан низької молекулярної маси, ацілірованний хітозан, хітоолігосахариди, карбоксіпропілхітозан), які були отримані при хімічній або ферментативній деградації вихідного продукту. Показано, що низькомолекулярні ацилірований і дезацетилірованний хітозани, краще розчиняються в нейтральних і лужних розчинах і краще всмоктуються з шлунково-

Вісник Сумського національного аграрного університету 
кишкового тракту, мають більш виражену антимікробну і антитоксичну активність в порівнянні з вихідним високомолекулярним хітозаном [8].

Налагоджена технологічна лінія виробництва природних полімерів хітину і хітозану, виділених з лялечок шовковичного шовкопряда Bombyx mori, використовуючи депротеїнізації розчином гідроксиду натрію, дезацетілірованіе отриманого хітину концентрованим розчином $\mathrm{NaOH}$. Встановлено оптимальний час синтезу хітозану - 3 год, температура процесу $\mathrm{T}=120-1300 \mathrm{C}$, концентрація $\mathrm{NaOH}$, яка становить $50 \%$ [1]. Хітозан як природний матеріал цінний тим, що його корисні властивості посилюються в поєднанні з іншими біокомпонентами $[13,18]$. Розширення знань про хітозан ставить перед технічною ентомологією завдання напрацювання високоякісного біоматеріалу комах, що стає можливим завдяки існуючим і розробці нових селекційних прийомів підвищення показників культури комах в умовах промислового розаведення. У звязку з вищевказаним набуває актуальності робота з існуючими в Україні породами та лініями шовковичного шовкопряда. Вагомі напрацювання Інституту шовківництва УААН (нині відділ шовківництва та технічної ентомології Національного наукового центру «ннститут експериментальної та клінічної ветеринарної медицини», м. Харків) залишились дотепер як унікальна колекція порід та гібридів шовковичного шовкопряду. Колекція має статус Національного надбання України, до складу якої входять породи селекції Інституту шовківництва УААН та завезені, в основному в період з 1948 по 2001 рр., з інших країн світу (Болгарії, Китаю, Росії, Румунії, Грузії, Франції, Індії, Узбекистану, Японії), які були успішно інтродуковані в умовах Харківщини. На сьогодні генетичний фонд шовковичного шовкопряду в Україні налічує 125 порід, з яких 20 є компонентами районованих та перспективних гібридів.

Лінії шовковичного шовкопряду Г2, Г4, Г6 та Г7 представляють інтерес для вивчення у зв'язку з високою шовконосністю та високим ступенем інбридингу, оскільки підлягали постійному жорсткому відбору за селекційними індексами за ознаками шовконосність та маса шовкової оболонки протягом одинадцяти поколінь з індивідуальним підбором пар для схрещування. Саме селекційні прийоми можуть сприяти підвищенню ефективності виробництва культур комах за для задоволення потреб сучасних високотехнологічних напрямів.

Метою досліджень $€$ вивчення високошовконосних високоінбредних ліній шовковичного шовкопряду Г2, Г4, Гб та Г7 за показниками життєздатності та продуктивності для одержання високоякісного біоматеріалу комах.

Матеріали та методи досліджень. Експериментальну частину роботи проводили в Інституті шовківництва УААН (відділ шовківництва та технічної ентомології Національного наукового центру «Інститут експериментальної та клінічної ветеринарної медицини», м. Харків). В якості контролю виступали порода Мерефра 6 (Мер.6), та міжпородний районований гібрид Мерефа 6 × Мерефра 7 (Мер.6×Мер.7).

Об'єкти дослідження: Лінії Г2 та Г4 є нащадками прямих та реципрокних поєднань порід Мересра 6 та Українська 19, а саме: Г2 - лінія одинадцяти поколінь індивідуального відбору за селекційними індексами гібриду Мерефа 6×Українська 20, а Г4 - лінія одинадцяти поколінь індивідуального відбору за селекційними індексами гібриду Українська 20 × Мерефа 6, Г6 - лінія одинадцяти поколінь індивідуального відбору за селекційними індексами гібриду Українська 20×Українська 21, Г7 - лінія одинадцяти поколінь індивідуального відбору за селекційними індексами гібриду Українська $21 \times$ Мерефра 6.

Схрещування проводили за повною діалельною схемою, яка включала 16 варіантів (табл. 1), а також контроль порода Мер.6 та районований гібрид Мер.6×Мер.7. Всі варіанти вигодовували по 50 мг у триразовій повторності, тобто всього в досліду було 54 варіанти

Розміщували повторності за схемою латинського прямокутника для нівелювання впливу вертикального та горизонтального градієнтів температур [5].

Система діалельних схрещувань дає найбільш повну генетичну інформацію щодо властивостей і ознак сільськогосподарських культур $[2,5,12]$. Облік показників проводили за загальноприйнятими у шовківництві методиками $[3,6,15]$.

Схема схрещувань - повна діалельна схема за Б. Гріффрінгом 4×4

Таблиця 1

\begin{tabular}{|c|c|c|c|c|}
\hline${ }^{\circ} \delta^{\lambda}$ & Г2 & $\lceil 4$ & $\Gamma 6$ & $\lceil 7$ \\
\hline$\Gamma 2$ & Г2 & $\Gamma 2 \times \Gamma 4$ & $\Gamma 2 \times \Gamma 6$ & $\Gamma 2 \times \Gamma 7$ \\
\hline$\Gamma 4$ & $\Gamma 4 \times \Gamma 2$ & $\Gamma 4$ & $\Gamma 4 \times \Gamma 6$ & $\Gamma 4 \times \Gamma 7$ \\
\hline$\Gamma 6$ & $\Gamma 6 \times \Gamma 2$ & $\Gamma 6 \times \Gamma 4$ & $\Gamma 6$ & $\Gamma 6 \times \Gamma 7$ \\
\hline$\Gamma 7$ & $\Gamma 7 \times \Gamma 2$ & $\Gamma 7 \times \Gamma 4$ & $\Gamma 7 \times \Gamma 6$ & $\Gamma 7$ \\
\hline
\end{tabular}

Результати досліджень. Показники ліній Г2, Г4, Г6 та Г7 порівнювали з показниками породи Мерефа 6, а міжлінійні гібриди - з районованим гібридом Мер.6×Мер.7. В таблиці 2 представлено порівняльну характеристику ліній Г2, Г4, Г6, Г7 та їх прямих і реципрокних гібридів за основними біологічними показниками. За показником життєздатності гусениць серед ліній вірогідно вищими за контроль були Г6 та Г2, які перевищували контроль на 8,35\% та $5,06 \%$ (ps0,001), а найкращою була лінія $\Gamma 7$, що на 13,61\% ( $p \leq 0,001)$ перевищувала Мер.6. Серед гібридів за життєздатністю гусениць достовірно перевищував контроль тільки Г7×Г4 (на 6,61\%) та генотипи Г7×Г2, Г6хГ7 знаходилися на рівні контролю, решта мали вірогідно нижчі значення. За показником урожаю сортових коконів на рівні контролю була лінія Г7, а серед гібридів найкращими були Г6хГ7 та Г7×Г4, але різниця не $\epsilon$ достовірною. За показником відсоток сортових коконів серед ліній Г7 була на рівні контролю, а серед гібридів вірогідно (p $\leq 0,001)$ перевищували контроль Мер.6×Мер.7 генотипи Г7×Г4 та Г6×Г2 на 6,98 \% та 7,15\% відповідно, а також на рівні $p \leq 0,05$ на $2,65 \%$ генотип $Г 4 \times\ulcorner 2$. За показником середної маса сортового кокону вірогідних відмінностей не спостерігалось. За сукупністю біологічних показників слід відмітити як найкращі гібридні комбінації $\lceil 6 \times\lceil 7$ та $\lceil 7 \times\lceil 4$, а серед ліній найкращими показниками за життєздатністю гусениць, урожаєм та відсотком сортових коконів переважала лінія Г7. 
Порівняльна характеристика основних біологічних показників ліній Г2, Г4, Г6, Г7 та їх гібридів (весняна вигодівля)

\begin{tabular}{|c|c|c|c|c|}
\hline Генотип & Життєздатність гусениць, \% & Урожай сортових коконів, кг & Сортові кокони, \% & Середня маса кокона, г \\
\hline$\Gamma 2$ & $79,70 \pm 5,835^{\star * *}$ & $2,60 \pm 0,211$ & $79,46 \pm 1,277^{\star \star \star}$ & $1,67 \pm 0,013$ \\
\hline$\Gamma 2 x \Gamma 4$ & $71,65 \pm 4,395^{\star * *}$ & $2,44 \pm 0,122$ & $80,23 \pm 1,912$ & $1,81 \pm 0,035$ \\
\hline$\Gamma 2 \times \Gamma 6$ & $78,12 \pm 4,574^{* *}$ & $2,91 \pm 0,187$ & $80,30 \pm 1,172$ & $1,92 \pm 0,060$ \\
\hline$\Gamma 2 x \Gamma 7$ & $75,06 \pm 3,365^{\star \star *}$ & $2,65 \pm 0,219$ & $77,32 \pm 3,061^{* * *}$ & $1,85 \pm 0,026$ \\
\hline$\Gamma 4$ & $76,29 \pm 2,584$ & $2,81 \pm 0,255$ & $81,37 \pm 4,656$ & $1,83 \pm 0,038$ \\
\hline$\Gamma 4 \times \Gamma 2$ & $74,76 \pm 6,123^{* * *}$ & $2,58 \pm 0,182$ & $84,04 \pm 1,509^{*}$ & $1,77 \pm 0,024$ \\
\hline$\Gamma 4 \times \Gamma 6$ & $57,53 \pm 1,748^{* * *}$ & $1,68 \pm 0,039$ & $66,72 \pm 1,625^{* * *}$ & $1,90 \pm 0,047$ \\
\hline$\Gamma 4 \times \Gamma 7$ & $66,61 \pm 6,779^{* * *}$ & $2,16 \pm 0,480$ & $69,41 \pm 7,382^{* * *}$ & $1,96 \pm 0,054$ \\
\hline$\Gamma 6$ & $82,99 \pm 1,528^{* * *}$ & $2,93 \pm 0,114$ & $79,53 \pm 0,681^{* * *}$ & $1,89 \pm 0,023$ \\
\hline$\Gamma 6 x \Gamma 2$ & $76,26 \pm 6,704^{* \star *}$ & $3,0 \pm 0,257$ & $88,54 \pm 1,789^{* * *}$ & $1,88 \pm 0,030$ \\
\hline$\Gamma 6 x \Gamma 4$ & $27,16 \pm 6,035$ & $0,72 \pm 0,203$ & $59,79 \pm 5,985$ & $1,95 \pm 0,051$ \\
\hline$\Gamma 6 x \Gamma 7$ & $82,84 \pm 7,451$ & $3,14 \pm 0,417$ & $83,92 \pm 4,490^{*}$ & $1,88 \pm 0,007$ \\
\hline$\Gamma 7$ & $88,25 \pm 2,387^{* * *}$ & $3,08 \pm 0,113$ & $84,47 \pm 1,995$ & $1,77 \pm 0,056$ \\
\hline$\Gamma 7 \times \Gamma 2$ & $80,82 \pm 2,529$ & $2,91 \pm 0,232$ & $81,71 \pm 4,665$ & $1,82 \pm 0,055$ \\
\hline$\Gamma 7 \times \Gamma 4$ & $87,46 \pm 1,770^{\star \star *}$ & $3,37 \pm 0,196$ & $88,37 \pm 4,651^{* * *}$ & $1,87 \pm 0,031$ \\
\hline$\Gamma 7 \times \Gamma 6$ & $67,24 \pm 8,063^{* *}$ & $2,34 \pm 0,544$ & $70,31 \pm 7,260^{* * *}$ & $1,99 \pm 0,074$ \\
\hline Мер.6 (контр.) & $74,64 \pm 5,518$ & $2,99 \pm 0,181$ & $83,0 \pm 2,546$ & $2,05 \pm 0,030$ \\
\hline Мер.6×Мер.7 (контр.) & $80,85 \pm 4,059$ & $3,24 \pm 0,324$ & $81,39 \pm 4,713$ & $2,10 \pm 0,035$ \\
\hline
\end{tabular}

В таблиці 3 наведені основні показники продуктивності ліній, що вивчаються. Достовірних відмінностей за масою кокону та масою оболонки як серед самок, так і серед самців ні між лініями, ні між гібридами від контролю не виявлено. Слід відмітити, що шовконосність майже всіх самців вірогід- но вища за контроль, у самок достовірне перевищення спостерігалось у Г2 та гібриду Г6хГ4, а у решти тенденція до підвищення, це пояснюється тим, що лінії Г2, Г4, Г6 та Г7 саме і були виведені шляхом відбору за селекційними індексами за шовконосністю.

Таблиця 3

Характеристика показників продуктивності ліній Г2, Г4, Г6, Г7 та їх гібридів (весняна вигодівля)

\begin{tabular}{|c|c|c|c|c|c|c|}
\hline \multirow{2}{*}{ Генотип } & \multicolumn{2}{|c|}{ Маса кокону, г } & \multicolumn{2}{|c|}{ Маса оболонки, мг } & \multicolumn{2}{|c|}{ ШовкОносність, \% } \\
\hline & самки & самця & самки & самця & самки & самця \\
\hline$\Gamma 2$ & $1,86 \pm 0,007$ & $1,45 \pm 0,009$ & $0,39 \pm 0,003$ & $0,36 \pm 0,003$ & $20,75 \pm 0,105^{*}$ & $25,11 \pm 0,152^{*}$ \\
\hline$\Gamma 2 \times \Gamma 4$ & $2,03 \pm 0,025$ & $1,57 \pm 0,012$ & $0,41 \pm 0,009$ & $0,40 \pm 0,007$ & $20,36 \pm 0,195$ & $25,21 \pm 0,319^{\star \star \star}$ \\
\hline$\Gamma 2 \times \Gamma 6$ & $2,12 \pm 0,013$ & $1,70 \pm 0,013$ & $0,42 \pm 0,006$ & $0,40 \pm 0,003$ & $19,84 \pm 0,176$ & $23,68 \pm 0,329$ \\
\hline$\Gamma 2 \times \Gamma 7$ & $2,02 \pm 0,050$ & $1,61 \pm 0,015$ & $0,41 \pm 0,015$ & $0,41 \pm 0,003$ & $20,42 \pm 0,222$ & $25,32 \pm 0,329^{\star \star \star}$ \\
\hline$\Gamma 4$ & $1,99 \pm 0,020$ & $1,54 \pm 0,017$ & $0,40 \pm 0,003$ & $0,38 \pm 0,007$ & $19,97 \pm 0,277$ & $24,41 \pm 0,373$ \\
\hline$\Gamma 4 \times\lceil 2$ & $1,97 \pm 0,053$ & $1,56 \pm 0,033$ & $0,41 \pm 0,007$ & $0,40 \pm 0,006$ & $20,66 \pm 0,262$ & $25,71 \pm 0,391^{\star \star *}$ \\
\hline$\Gamma 4 \times \Gamma 6$ & $2,10 \pm 0,045$ & $1,60 \pm 0,019$ & $0,42 \pm 0,010$ & $0,39 \pm 0,003$ & $20,0 \pm 0,056$ & $24,53 \pm 0,085$ \\
\hline$\lceil 4 \times\lceil 7$ & $2,19 \pm 0,026$ & $1,70 \pm 0,038$ & $0,42 \pm 0,007$ & $0,41 \pm 0,003$ & $19,33 \pm 0,114$ & $23,98 \pm 0,365$ \\
\hline$\Gamma 6$ & $2,04 \pm 0,030$ & $1,57 \pm 0,027$ & $0,41 \pm 0,007$ & $0,37 \pm 0,023$ & $20,23 \pm 0,230$ & $23,39 \pm 1,356$ \\
\hline$\Gamma 6 \times \Gamma 2$ & $2,06 \pm 0,026$ & $1,60 \pm 0,026$ & $0,42 \pm 0,007$ & $0,42 \pm 0,007$ & $20,23 \pm 0,115$ & $26,05 \pm 0,298^{\star \star *}$ \\
\hline$\Gamma 6 \times \Gamma 4$ & $2,09 \pm 0,008$ & $1,69 \pm 0,021$ & $0,46 \pm 0,008$ & $0,44 \pm 0,013$ & $21,91 \pm 0,362^{\star * *}$ & $25,92 \pm 0,674^{\star * \star}$ \\
\hline$\Gamma 6 \times \Gamma 7$ & $2,06 \pm 0,013$ & $1,59 \pm 0,007$ & $0,42 \pm 0,003$ & $0,39 \pm 0,006$ & $20,52 \pm 0,255$ & $24,48 \pm 0,375^{\star *}$ \\
\hline$\Gamma 7$ & $1,99 \pm 0,039$ & $1,53 \pm 0,036$ & $0,40 \pm 0,010$ & $0,36 \pm 0,006$ & $20,13 \pm 0,146$ & $23,54 \pm 0,214$ \\
\hline$\Gamma 7 \times \Gamma 2$ & $1,99 \pm 0,020$ & $1,61 \pm 0,023$ & $0,39 \pm 0,003$ & $0,39 \pm 0,006$ & $19,80 \pm 0,249$ & $24,18 \pm 0,305$ \\
\hline$\Gamma 7 \times \Gamma 4$ & $2,03 \pm 0,010$ & $1,66 \pm 0,040$ & $0,41 \pm 0,007$ & $0,41 \pm 0,013$ & $20,03 \pm 0,291$ & $24,49 \pm 0,419^{* *}$ \\
\hline$\Gamma 7 \times \Gamma 6$ & $2,27 \pm 0,038$ & $1,76 \pm 0,020$ & $0,45 \pm 0,009$ & $0,43 \pm 0,010$ & $19,66 \pm 0,486$ & $24,43 \pm 0,294$ \\
\hline Мер. 6 (конт.) & $2,20 \pm 0,035$ & $1,79 \pm 0,062$ & $0,43 \pm 0,009$ & $0,41 \pm 0,017$ & $19,73 \pm 0,361$ & $22,94 \pm 0,236$ \\
\hline Mep.6×Mер.7 (конт.) & $2,41 \pm 0,026$ & $1,84 \pm 0,036$ & $0,46 \pm 0,006$ & $0,41 \pm 0,009$ & $19,09 \pm 0,051$ & $22,46 \pm 0,058$ \\
\hline
\end{tabular}

Примітка: *** $p \leq 0,001 ; * * 0 \leq 0,01 ;{ }^{*} p \leq 0,05$

Показник життєздатності гусениць є одним з найважливіших біологічних показників, як породи та лінії, так і гібриду. Тому лінії Г2, Г4, Г6, Г7 вивчали за життєздатністю гусениць і в літню вигодівлю, умови якої наближені до песимального фону - гірша якість листя, понижена температура повітря на 2-3 ${ }^{\circ} \mathrm{C}$ для кожного віку гусениць (рис. 1). Як вид- но з рисунку 1, найвищою життєздатністю відрізнялась лінія Г6 71,8 4,18 \%. Ї̈̈ прямі гібриди з іншими лініями мали стабільно високі показники в межах 79,8-83,1\%, реципрокні іiї комбінації з Г2 та Г7 також мали значні показники $(79,14$ та 78,98 \% відповідно), що вказує на високу специфічну комбінаційну здатність лінії Г6 за життєздатністю гусениць. 


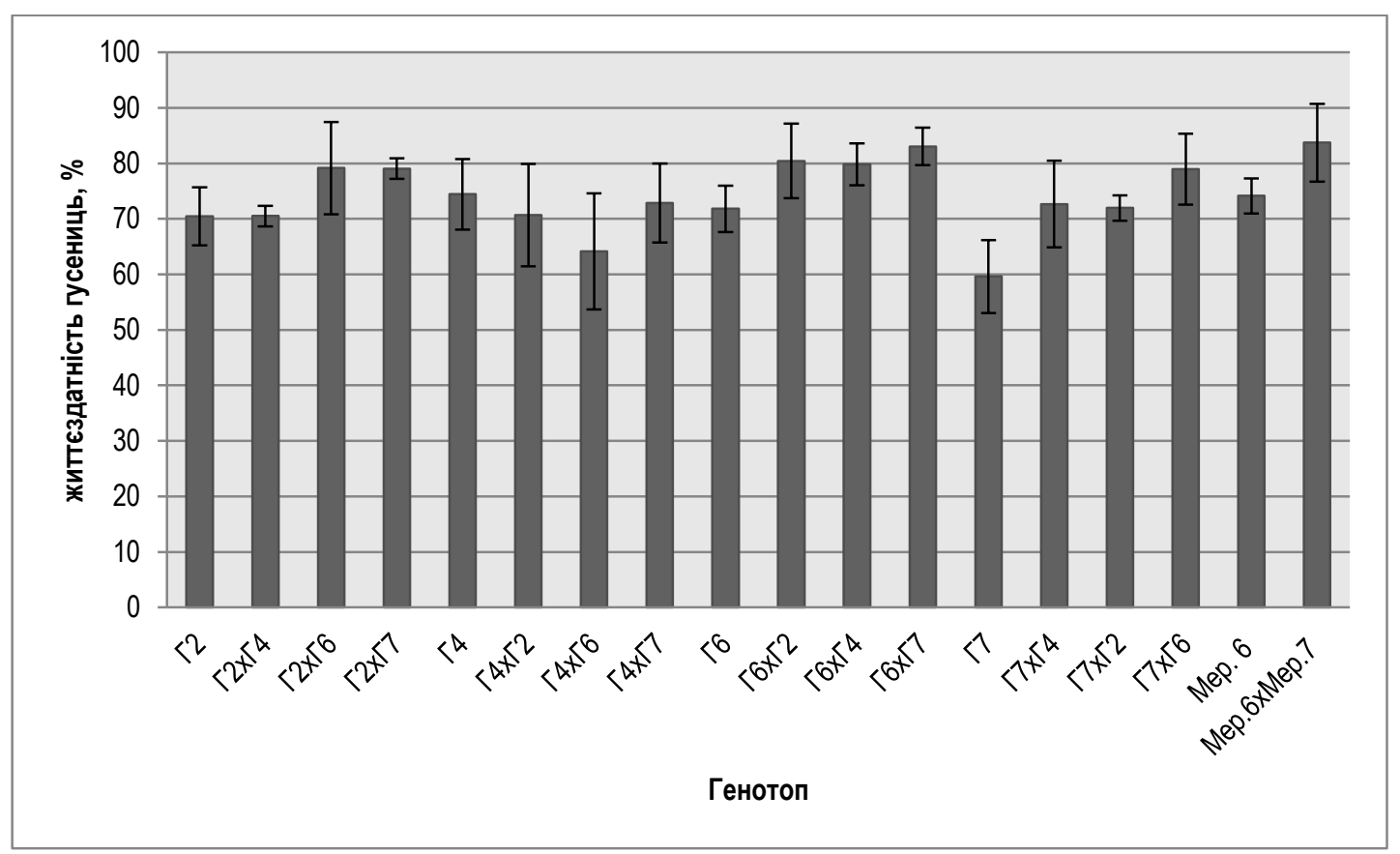

Рис. 1. Життєздатність гусениць ліній Г2, Г4, Г6, Г7 та ї гібридів

у порівнянні з контролем (Мер.6 та гібридом Мер.6×Мер.7) в умовах літньої вигодівлі

Для задоволення різноманітних потреб сучасних високотехнологічних напрямів існує цілий ряд вимог до високоякісного біоматеріалу. Перший етап селекційної роботи заключається у виборі вихідного матеріалу, оскільки його показники значно впливають на наступні покоління. Аніліз ліній Г2, Г4, Г6, Г7 показав, що за сукупністю технологічних та біологічних показників, а також гетерозисного есекту при їх схрещуванні переважали лінії Г6 та Г7, які доцільно використовувати в подальшій роботі, спрямованій на отримання високожиттєздатного біоматеріалу. Зокрема, вивчення передачі маркерного гену white $\left(\mathrm{w}^{2}\right)$ передбачає схрещування 3 низькожиттєздатною породою Совєтська 5 (Сов. 5.), тому для підвищення показника життєздатності її потрібно схрещувати з високо життєздатною лінією з високою комбінаційною здатністю. Разом з тим лінія Г7 була відібрана для вивчення зв'язку між ознакою «рисунок гусениць» та показниками життєздатності та продуктивності шовковичного шовкопряду на гусеничній стадії розвитку. Крім того вона $є$ перспективною для подальшого відбору за співвідношенням довжини до ширини кокона та виведення ліній з округлою та видовженою формою кокону.

Висновки. 1. Проведена порівняльна характеристи- ка високошовконосних високоінбредних ліній шовковичного шовкопряду Bombyx mori Г2, Г4, Г6 та Г7 за показниками життєздатності та продуктивності. За сукупністю біологічних та технологічних показників як найкращі були виділені лінії Г6 та Г7.

2. 3 найкращими показниками за життєздатністю гу-

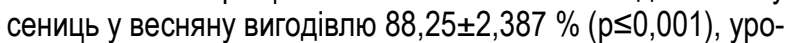
жаєм сортових коконів 3,08 $\pm 0,113$ кг та відсотком сортових

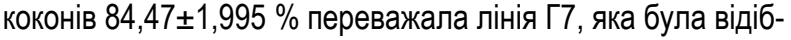
рана для вивчення гусеничної стадії та формотворення коконів.

3. За результатами літньої вигодівлі була відібрана як найкраща лінії Г6, що відрізнялася найвищою життєздатністю за показником життєздатності гусениць 71,8土 4,18 \%. Ï̈̈ прямі гібриди з іншими лініями та реципрокні комбінації з Г2 та Г7 мали стабільно високі показники в межах 79,8-83,1 \% та 79,14 та 78,98 \% відповідно, що вказує на високу специфічну комбінаційну здатність лінії за показником, що вивчається.

4 Проведені дослідження є підґрунтям для проведення дослідних робіт за даною селективною ознакою 3 метою отримання високожиттєздатного матеріалу.

\section{Список використаної літератури:}

1. Бекчанов И.К., Рашидова С.Ш. Технологическая линия получения природных полисахаридов - хитина и хитозана Bombyx mori. Universum: технические науки : электрон. научн. журн. $2019 . \quad$ № 12 (69). URL: https://7universum.com/ru/tech/archive/item/8441

2. Браславский М.Е., Головко В.А., Злотин А.З. Селекция тутового шелкопряда в Украине (достижения, проблемы и перспективы). Харьков, 2002. 280 с.

3. Ворошилов Н. В. Методические указания по принципам селекции энтомофагов. - Л.: ВИЗР. 1979. 32 с.

4. Вохидова Н.Р., Рашидова С.Ш. Полимер металлические системы хитозана Bombyx mori Акад. наук Респ. Узбекистан, Ин-т химии и физики полимеров, М-во высш. и сред. спец. образования Респ. Узбекистан и др. Ташкент : Фан. 2016. $128 \mathrm{c}$.

5. Доспехов Б.А. Методика полевого опыта (с основами статистической обработки результатов исследований) М. : Книга по Требованию. 2012. 352 с.

6. Злотин А.З. Техническая энтомология : справочное пособие К. : Наук. думка, 1989. 183 с. 
7. Злотін О.3., Маркіна Т.Ю. Біоіндикація стану природного середовища. Навчальний посібник для студентів вищих навчальних закладів. Харків : ХНПУ імені Г.С. Сковороди. 2014. 114 с.

8. Иванушко Л.А., Соловьева Т.Ф., Запорожец Т.С., Сомова Л. М., Горбач В.И. Антибактериальные и антитоксические свойства хитозана и его производных. Тихоокеанский медицинский журнал. Владивосток. 2009. №3, С. 82-85

9. Маркина Т.Ю. Гомеостатические свойства искусственных популяций насекомых и способы управления их состоянием : монографияя. Х:: Планета-Принт, 2019. 380 с.

10. Милушева Р.Ю., Пирниязов К.К., Рашидова С.Ш. Очистка хитозана Bombyx Mori. Вестник ТвГУ. Серия «Химия». 2016. № 2. С. 119-124

11. Рашидова С.Ш., Милушева Р.Ю. Хитин и хитозан Bombyx mori. Синтез, свойства и применение. Ташкент. 2009. $246 \mathrm{c}$.

12. Рокицкий П.Ф. Введение в статистическую генетику. Минск: Вышэйшая школа, 1978. 448 с.

13. Скрябин К.Г, Михайлов С.Н., Варламов В.П. Хитозан. Москва: Центр «Биоинженерия» 2013. 18 с.

14. Скрябин К.Г., Вихорева Г.А., Варламов В.П. Хитин и хитозан: Получение, свойства и применение Москва, Наука, 2002. 360 c

15. Тамарина Н. А. Основы технической энтомологии. М. : МГУ, 1990. 204 с.

16. Шукуров И.Б., Шукурова В.И., Шукурова С.И., Сулейманов С.Ф. Исследование механизма действия хитозана при лечении термихеских ожогов. Вісник проблем біології і медицини, Полтава 2012. Вип. 1 (91), С. 191-193

17. Ghosh S., Haldar P., Mandal D. K. Suitable food plants for mass rearing of the short-horn grasshopper Oxya hyla hyla (Orthoptera: Acrididae). European Journal of Entomology. 2014. Vol. 111, №3. pp. 448-452.

18. Manni L., Ghorbel-Bellaaj O., Jellouli K., Younes I., Nasri M. Extraction and characterization of chitin, chitosan, and protein hydrolysates prepared from shrimp waste by treatment with crude protease from Bacillus cereus SV1. Appl. Biochem. Biotechnol. 2010. 162:345-357. DOI: 10.1007/s12010-009-8846-y

19. Morales-Ramos Juan A., Guadalupe Rojas M., Shapiro-llan David I. (Eds.) Mass Production of Beneficial Organisms, Invertebrates and Entomopathogens. Academic Press, 2013. 764 p.

20. Raubenheimer D., Rothman J. M. Nutritional Ecology of Entomophagy in Humans and Other Primates Annu. Rev. Entomol. 2013. Vol. 58, pp. 141-160.

21. Vokhidova N. R., Sattarov M. E., Kareva N. D., Rashidova S. Sh. Fungicide Features of the Nanosystems of Silkworm (Bombyx mori) Chitosan with Copper lons. Microbiology, 2014, Vol. 83, No. 6, pp. 751-753 DOI: 10.1134/S0026261714060204

\section{References:}

1. Bekchanov I.K. and Rashidova S.Sh., 2019. Tehnologicheskaja linija poluchenija prirodnyh polisaharidov - hitina i hitozana Bombyx mori [Technological line for producing natural polysaccharides - chitina and chitozan Bombyx Mori] Universum: tehnicheskie nauki : jelektron. nauchn. zhurn. issue 12 (69). URL: https://7universum.com/ru/tech/archive/item/8441

2. Braslavskij M.E., Golovko V.A. and Zlotin A.Z., 2002. Selekcija tutovogo shelkoprjada v Ukraine (dostizhenija, problemy i perspektivy) [Silkworm breeding in Ukraine (achievements, problems and prospects)] Har'kov, $280 \mathrm{p}$.

3. Voroshilov N.V., 1979. Metodicheskie ukazanija po principam selekcii jentomofagov [Methodological guidelines on the principles of entomophage artificial selection] Leningrad: VNII Zashchiti rasteniy, $22 \mathrm{p}$.

4. Vohidova N.R. and Rashidova S.Sh., 2016. Polimer metallicheskie sistemy hitozana Bombyx mori [Bombyx mori chitosan polymer metal systems] Akademya nauk Respubliki Uzbekistan, Institut himii i fiziki polimerov, Ministerstvo vysshego i srednego special'nogo obrazovanija Respubliki Uzbekistan Tashkent : Fan, 128 p.

5. Dospehov B.A., 2012. Metodika polevogo opyta (s osnovami statisticheskoj obrabotki rezul'tatov issledovanij) [Field experiment technique (with the basics of statistical processing of research results)] Moskva : Kniga po Trebovaniju, $352 \mathrm{p}$.

6. Zlotin A.Z., 1989. Tehnicheskaja jentomologija : spravochnoe posobie [Technical entomology: a reference book] Kiev : Naukova dumka, $183 p$.

7. Zlotin O.Z. and Markina T.Yu., 2014. Bioindykatsiia stanu pryrodnoho seredovyshcha. [Bioindication of the state of the natural environment.] Navchalnyi posibnyk dlia studentiv vyshchykh navchalnykh zakladiv. Kharkiv : KhNPU imeni H.S. Skovorody, 114 p. (In Ukrainian).

8. Ivanushko L.A., Solov'eva T.F., Zaporozhec T.S., Somova L. M. and Gorbach V.I., 2009. Antibakterial'nye i antitoksicheskie svojstva hitozana i ego proizvodnyh [Antibacterial and antitoxic properties of chitosan and its derivatives] Tihookeanskij medicinskij zhurnal. Vladivostok. issue 3, pp. 82-85.

9. Markina T.Ju., 2019. Gomeostaticheskie svojstva iskusstvennyh populjacij nasekomyh i sposoby upravlenija in sostojaniem : monografija [Homeostatic properties of artificial insect populations and methods of controlling their state] Har'kov : Planeta-Print, $380 \mathrm{p}$.

10. Milusheva R.Ju., Pirnijazov K.K. and Rashidova S.Sh., 2016. Ochistka hitozana Bombyx Mori. [Purification of Bombyx Mori Chitosan] Vestnik Tverskogo gosudarstvennogo universiteta. Serija «Himija». issue 2. pp. 119-124.

11. Rashidova S.Sh. and Milusheva R.Ju., 2009. Hitin i hitozan Bombyx mori. Sintez, svojstva i primenenie [Chitin and chitosan Bombyx mori. Synthesis, properties and application] Tashkent, $246 \mathrm{p}$.

12. Rokickij P.F., 1978. Vvedenie v statisticheskuju genetiku [An introduction to statistical genetics] Minsk: Vyshjejshaja shkola, $448 \mathrm{p}$.

13. Skrjabin K.G, Mihajlov S.N. and Varlamov V.P., 2013. Hitozan [Chitosan.] Moskva : Centr «Bioinzhenerija» 18 p.

14. Skrjabin K.G., Vihoreva G.A. and Varlamov V.P., 2002. Hitin i hitozan: Poluchenie, svojstva i primenenie [Chitin and 
chitosan: Production, properties and application] Moskva : Nauka, $360 \mathrm{p}$.

15. Tamarina N.A., 1990. Osnovy tehnicheskoj jentomologii [Fundamentals of technical entomology] Moskva : MGU, 204

p.

16. Shukurov I.B., Shukurova V.I., Shukurova S.I., and Sulejmanov S.F., 2012. Issledovanie mehanizma dejstvija hitozana pri lechenii termiheskih ozhogov [Study of the mechanism of action of chitosan in the treatment of thermal burns] Visnyk problem biolohii i medytsyny. Poltava. issue 1 (91), pp. 191-193.

17. Ghosh S., Haldar P. and Mandal D. K. Suitable food plants for mass rearing of the short-horn grasshopper Oxya hyla hyla (Orthoptera: Acrididae). European Journal of Entomology. 2014. Vol. 111, №3. pp. 448-452.

18. Manni L., Ghorbel-Bellaaj O., Jellouli K., Younes I., and Nasri M., 2010. Extraction and characterization of chitin, chitosan, and protein hydrolysates prepared from shrimp waste by treatment with crude protease from Bacillus cereus SV1. Appl. Biochem. Biotechnol. 162:345-357. DOI: 10.1007/s12010-009-8846-y

19. Morales-Ramos Juan A., Guadalupe Rojas M. and Shapiro-llan David I. (Eds.), 2013. Mass Production of Beneficial Organisms, Invertebrates and Entomopathogens. Academic Press. 764 p.

20. Raubenheimer D. and Rothman J. M., 2013. Nutritional Ecology of Entomophagy in Humans and Other Primates Annu. Rev. Entomol. Vol. 58, pp. 141-160.

21. Vokhidova N. R., Sattarov M. E., Kareva N. D. and Rashidova S. Sh., 2014. Fungicide Features of the Nanosystems of Silkworm (Bombyx mori) Chitosan with Copper lons. Microbiology, Vol. 83, issue 6, pp. 751-753 DOI: 10.1134/S0026261714060204

Panchenko Olha Mykhailivna, researcher, Institute of Animal Husbandry NAAS, (Kharkiv, Ukraine)

Markina Tetiana Yuriivna, Doctor of Biological Sciences, Professor, G.S. Skovoroda Kharkiv National Pedagogical University, (Kharkiv, Ukraine)

Evaluation of high-silk lines of of silkworm (Bombyx Mori L.) for viability and productivity

The article presents the results of studies of high-silk high-inbred lines of silkworm Bombyx mori L. G2, G4, G6 and G7 in terms of viability and productivity to obtain high quality insect biomaterial. Selective lines are of interest for study due to high silkiness and high inbreeding, as they were subject to constant rigorous selection by selection indices for silkiness and silk weight for eleven generations with individual selection of pairs for crossing. It is selection techniques that can increase the efficiency of insect production to meet the needs of modern high-tech areas. Comparative evaluation of high-silk high-inbred lines in terms of viability and productivity showed that the set of biological and technological indicators as the best were the lines G6 and G7. With the best indicators of viability of caterpillars in spring feeding $88.25 \pm 2.387 \%$ ( $p \leq 0.001)$, the yield of varietal cocoons $3.08 \pm 0.113 \mathrm{~kg}$ and the percentage of varietal cocoons $84.47 \pm 1.995 \%$ was dominated by line $\mathrm{G} 7$, which was selected for the study of caterpillars stages and formation of cocoons. According to the results of summer feeding was selected as the best - line G6, which had the highest viability of caterpillars $(71.8 \pm 4.18 \%)$ and its direct hybrids with other lines, which had consistently high rates in the range of 79.8-83, 1\%. Reciprocal combinations of the $\mathrm{G} 6$ line with $\mathrm{G} 2$ and $\mathrm{G} 7$ also had high caterpillar viability (79.14 and 78.98\%, respectively). This indicates a high specific combination ability of the line on the indicator under study, which is the basis for research work on this selective feature. The development of high-quality biomaterial of silkworm helps to expand the possibilities of its use in various fields. In pharmacology and medicine, as a source of chitosan, in the environmental sphere, as a test object of bioindication research, in animal husbandry, as a valuable feed resource. Traditional areas of its use, in particular as a producer of natural silk, remain relevant.

Key words: Bombyx mori L. silkworm, selection, insect breeding, lines and hybrids, viability, productivity.

Дата надходження до редакції: 11.12 .2020 р. 